\title{
HUMAN RIGHTS IMPLICATIONS OF MANDATORY PREMARITAL HIV TESTING IN NIGERIA
}

\author{
EBENEZER DUROJAYE* AND \\ VICTORIA BALOGUN**
}

\begin{abstract}
*Research Assistant, Department of Constitutional Law and Philosophy of Law, University of the Free State, South Africa. E-mail: durojayeET.RD@ufs.ac.za

**Advocate of the High Court of Lesotho and Research Assistant, University of Kwazulu Natal, South Africa
\end{abstract}

\section{ABSTRACT}

This article considers the implications of public health policy on the enjoyment of individuals' fundamental rights. It specifically examines the appropriateness of mandatory premarital human immunodeficiency virus (HIV) testing in Nigeria. In doing this, the article discusses the importance of health as a human right, explains the relationship between public health and human rights, and the impact of the HIV/acquired immunodeficiency syndrome pandemic in Nigeria. Arguments in favour of mandatory premarital HIV testing are critically examined and specific human rights that may be violated by this policy are discussed. In conclusion, the article argues that this policy will do more harm than good in curbing the spread of the epidemic in Nigeria.

\section{IN T R O D U CT I O N}

The human immunodeficiency virus (HIV) epidemic is one of the greatest challenges facing humanity in the past twenty years or more. The impact of the epidemic in sub-Saharan Africa is more debilitating than in other parts of the world. This region is said to account for about 22 million out of the total number of 33 million people said to be living with HIV worldwide at the end of 2007 (UNAIDS, 2008), when it was estimated by the United Nations Joint programmes on HIV/ AIDS (UNAIDS) that about 2.1 million people died of HIV/acquired immunodeficiency syndrome (AIDS)-related complications. Seventy per cent of these deaths occurred in sub-Saharan Africa. Women are worst affected, constituting about $50 \%$ of world figure and about $60 \%$ of people infected in Africa (UNAIDS, 2008).

In a bid to curb the spread of the epidemic in Nigeria, a number of suggestions, steps, and policies are being considered. One, which many (c) The Author 2010. Published by Oxford University Press. All rights reserved. For Permissions, please email: journals.permissions@oxfordjournals.org. 
believe will help in addressing the spread of the epidemic, is that couples should be made to undergo HIV testing prior to marriage. Religious organizations often impose mandatory HIV testing as a condition for a wedding. Thus, the fundamental rights of couples to make choices with regard to their bodies are often undermined. This can be contrasted with the more acceptable approach of voluntary counselling and testing, which emphasizes pre-and post-test counselling, informed consent, and confidentially of the test result.

Already some faith-based organizations have started to implement a policy of requiring a 'certificate of HIV test' before coming to the altar. ${ }^{1}$ Indeed, there have been cases where weddings have been refused because one of the couples tested positive for HIV. Narrating a personal experience, Ibekwe explains as follows:

My wife and I lived together from January of 1995 after our traditional marriage and got a date in April of that same year for our church wedding. But part of the conditions to be met before marriage in the Catholic Church in Onitsha, where we stay, was an HIV antibody test. Without pre-test counseling, my wife and I took the HIV antibody test, and the result was positive for my wife and negative for me. First, the church announced the revocation of the wedding. When we insisted, our parents were invited. The priest asked our parents if they knew our serostatus. They said yes. The church took time to explain the implications to our parents, but they still supported the marriage. The church thereafter agreed to wed us. ${ }^{2}$

Many people have been calling on the government for a national policy or law making it compulsory for intending couples to undergo an HIV test. ${ }^{3}$ However, what are the implications or advantages of the policy of mandatory premarital HIV testing in Nigeria? Is such a policy likely to stand the test of time or will it be fruitful at the end of the day? What are the public health and human rights implications of such a policy? This article intends to provide answers to some of these questions. Firstly, the article examines the importance of health as a human right. Secondly, it explains the relationship between public health and human rights. The impact of HIV/AIDS in Nigeria is then considered. The arguments in favour of mandatory premarital HIV testing are critically examined and specific human rights that may be violated by this policy are discussed. In conclusion, the article argues that this policy will do more harm than good in curbing the spread of the epidemic in Nigeria.

THE RIGHT TO HEALTH UNDER INTERNATIONAL LAW

Health was first conceived as a human right by the World Health Organization in the preamble to its Constitution where it was stated that the attainment of the highest standard of physical and mental health is a fundamental right of everyone. ${ }^{4}$ Subsequently, the right to 
health has been accorded recognition in other international and regional human rights instruments. Article 25 of the Universal Declaration of Human Rights guarantees the right of everyone to a standard of health care adequate for him/her and his/her family including medical care ${ }^{5}$ However, by far the most detailed provision on the right to health is found in Article 12 of the International Covenant on Economic, Social and Cultural Rights (ICESCR) ${ }^{6}$ where it is provided that 'The States parties to the present Covenant recognize the right of everyone to the enjoyment of the highest attainable standard of physical and mental health'. It goes on to recognize other determinants of health in its subsection 2 that include reduction in stillbirth and infant mortality rates, improvement of environmental and industrial hygiene, and so on. ${ }^{7}$

The Committee monitoring the implementation of the ICESCR in its General Comment $14^{8}$ has noted that the right to health, as contained in these instruments, does not in any way guarantee perfect health for all. However, it is not in contention that this right encompasses an obligation on a state to ensure access to both curative and preventative health services for all. In other words, states are legally obligated to ensure access to comprehensive health-care services, including services related to sexual and reproductive health such as access to HIV/AIDS medicines and contraceptive services for women. The Committee further notes that the right to health contains both freedoms and entitlements. That means that an individual should have the right to control one's body and health, including sexual and reproductive health freedom, and the right to be free from coercive medical treatment and experimentation. ${ }^{9}$ On the other hand, the entitlements relate to the right to 'a system of health protection which provides equality of opportunity for people to enjoy the highest attainable level of health' ${ }^{10}$ More importantly, the Committee advises that the right to health as guaranteed in Article 12 of the ICESCR should be construed as an inclusive right limited not only to the provision of timely and appropriate health-care services but also intersecting with determinants of health such as access to safe and potable water and sanitation, an adequate supply of food, nutrition and housing, healthy environmental conditions, and access to healthrelated information and education.

The Committee has also identified the essential elements of the right to health to include availability, accessibility, acceptability, and quality. According to the Committee, health-care good and services should be made available to all in sufficient quantity. Accessibility relates to four important elements namely, non-discrimination, physical, economic, and information accessibility. In summary, the Committee is of the view that health-care services should attend to the needs of all categories of people, especially the vulnerable and 
marginalized groups such as women, children, people with disability, and people living with HIV. ${ }^{11}$

It must be noted that the enjoyment of the right to health is also dependent on other rights such as right to life, dignity of person, freedom from inhuman and degrading treatment, liberty and nondiscrimination. Conversely, a violation of the right to health may implicate other rights such as life, human dignity, privacy, liberty, and non-discrimination. It has been held that a denial of emergency treatment to an individual infringes his right to life. ${ }^{12}$ The Human Rights Committee in its Comment 6 has observed that the right to life in Article 6 of the Covenant on Civil and Political Rights should be broadly interpreted so as to embrace other rights such as housing, food, and medical care. ${ }^{13}$ However, it is apt to point out that the right to health like other socio-economic rights has been criticized for being indefinite, vague, and subject to the challenge of nonjusticiability (Fidler, 1999). Thus, the constitutions of many countries of the world merely recognize the right to health as directive principles of government policy without imposing legal obligations on the governments of these countries. ${ }^{14}$

At the regional level, the right to health is guaranteed in virtually all the regional human rights instruments. For instance, Article 16 of the African Charter ${ }^{15}$ provides that everyone has the right to enjoy the best attainable state of physical and mental health. A similar provision exists in Article 14 of the Protocol to the African Charter on the Rights of Women (African Women's Protocol). ${ }^{16}$ The Protocol further provides that states should respect and promote a woman's right to control her fertility, decide the number and spacing of her children, choose any method of contraception, self-protection from sexually transmitted infections including HIV/AIDS, legal abortion in certain situations, and family planning. By these elaborate provisions, the Protocol has become the first international human rights instruments to explicitly recognize women's reproductive health as a human right and contains specific provisions on women's protection in the context of HIV/AIDS (Center for Reproductive Rights, 2005; Durojaye, 2006). Also, under Article 14 of the African Charter on the Rights and Welfare of the Child (African Children's Charter), the right to health of all children is guaranteed. The African Commission on Human and Peoples' Rights (African Commission) in the Purohit case ${ }^{17}$ has held that the 'Enjoyment of the human right to health as it is widely known is vital to all aspects of a person's life and well-being, and is crucial to the realization of all the other fundamental human rights and freedoms'. Although the right to health is not explicitly recognized under the Nigerian Constitution, the country has ratified most of these instruments and has actually incorporated the African Charter into its domestic law. ${ }^{18}$ 
There has always been tension between public health policies and individuals' rights. While the concern of public health has been the welfare of the community, little attention has been accorded individuals' rights. This tension has necessitated judicial intervention in the celebrated US case of Jacobson $v$ Massachusetts. ${ }^{19}$ In that case, the issue was whether a state could forcibly vaccinate a citizen against his will in order to protect the public from smallpox infection. The plaintiff in that case had refused vaccination claiming that it was a violation of his right to liberty. Upholding the conviction of the plaintiff, the US Supreme Court had noted that, based on the principle of paramount necessity, a state or community has the right to protect itself against an epidemic of a disease that threatens the safety of its members. It is instructive to note that, although the Court in that case did affirm the need for the protection of the community to override individuals' rights, it also pointed out that public health laws or policies should not be applied in an arbitrary or oppressive manner. Parmet et al (2005) have noted that this latter observation of the Court has been interpreted as constituting potential legal limits to the public health powers of a state. In other words, a state or community might need to balance the interest of the public with infringement on individuals' rights in adopting a public health policy.

The main aim of linking human rights and health is the advancement of human well-being. In expounding the linkages between human rights and health, Mann et al (1994) have suggested three important frameworks. Firstly, they note that public health policies, programmes, or practices may adversely affect the enjoyment of human rights. For instance, while a public health policy to quarantine people infected with swine flu or Ebola fever may be justified, it may, in the case of HIV/AIDS, infringe their rights to liberty and human dignity. This is because, while the swine flu and Ebola fever remain great threats to lives, HIV/AIDS has now almost been reduced to a manageable chronic disease due to availability of antiretroviral therapy. Moreover, the modes of transmission of swine flu are highly contagious and can be transmitted through casual contact unlike the case of HIV, which can only be contracted through sexual intercourse, blood transfusion, and from a pregnant woman to the child.

Secondly, human rights violation may lead to health-related problems. For instance, cases of violence against women or torture of prisoners may result in serious health complications for the victims. Torture, rape, or maltreatment of others has been shown to have long-lasting effects on the physical and mental well-being of individuals (Goldfeld et al, 1988). In the context of HIV/AIDS, denial of basic rights such as information, employment, education, or association may fuel 
vulnerability to HIV/AIDS and lack of care for infected persons. ${ }^{20}$ Thirdly, human rights and health are complementary. Thus, the promotion and protection of human rights will ultimately lead to the promotion and protection of health. For example, it has been shown that a higher socio-economic status may lead to better health status (Durton and Levine, 1989). Similarly, in the wake of the HIV/AIDS pandemic, experience has shown that lack of respect for human rights of people, especially the reproductive and sexual rights of women, renders them vulnerable to the epidemic (Albertyn, 2000). For instance, the inability of women to negotiate the use of a condom with their partners compromises their sexual and reproductive rights and at the same time predisposes them to HIV infection.

It must be noted that the ICECSR, which guarantees socio-economic rights, including the right to health, permits limitation of these rights in so far as they may be compatible with the nature of these rights and solely for the purpose of promoting the general welfare in a democratic society. ${ }^{21}$ The implication of this is that the right to health can be limited in certain circumstances, provided such limitations are justifiable and in the best interests of the community. The ICESCR, for instance, requires state parties to take steps aiming at "prevention, treatment and control of epidemic, endemic, occupational and other diseases'.$^{22}$ According to Gostin and Berkman (2007), this provision would seem to permit compulsory measures such as vaccination, treatment, or isolation to protect public health in certain circumstances. In other words, mandatory testing may be permissible only if it is clearly necessary and effective in protecting public health, is performed by public health officials, and the least intrusive means are being used. However, compulsory testing should be restricted to individuals known or at least suspected to be infected and should be done in a fair and non-discriminatory way. Following from this, the issue is not so much whether a state can adopt a public health policy that will subject individual's rights to the interests of the community, but whether such a policy has been thought through, can be justified and has complied with international human rights standards.

It is important for policy makers to know that, while conceiving public health policies, they should have in mind the implications of such policies on human rights. Echoing the view of Mann et al (1994), every public health policy should be viewed as a potential threat to human rights, unless proved otherwise. In designing any public health policy, particularly in the context of HIV/AIDS, the respect, protection, and fulfilment of all human rights should be the primary consideration of governments. This is so, as noted by Gruskin and Tarantola (2000), not because they are the legally binding obligations of governments but also because they are critical to an effective response to the pandemic. 
The first reported official case of HIV infection in Nigeria was in $1986 .{ }^{23}$ At this time, there was a great opportunity for the Nigerian government to nip in the bud the spread of the epidemic. However, the whole nation was in complete denial of the epidemic. As observed by Kirby (2004), the reaction at that time was given to moralizing and stigmatizing those infected as unclean, immoral, and dangerous to the community. This culminated in a near state of inaction on the part of the government. Successive military governments that ruled the country between 1985 and 1998 did not have clear-cut policies or programmes to address the HIV/AIDS epidemic. Thus, the HIV/AIDS pandemic continued to devastate the country. Nigeria, the most populous country in Africa, has an estimated 3.6 million people living with HIV, with a national seroprevalence rate of $4.4 \%$ (Federal Ministry of Health, 2005). Many more are affected in their roles as children, wives, husbands, friends, and family relations. The risk of HIV/AIDS for women is rising. By the end of 2003, there were an estimated 1,900,000 women living with HIV in Nigeria (UNAIDS, 2004). Women are particularly at risk because they lack enough power to negotiate safer sex and earn lower incomes. Moreover, women have access to less entitlement to assets and are caught within cultures that deny them ownership of their bodies. UNAIDS (2004) has estimated that about 2.5 of the 200 million women worldwide who become pregnant each year are infected with HIV. In a random sampling of pregnant women attending prenatal clinics in selected sites across Nigeria, 5 in every 100 tested were found positive (Federal Ministry of Health, 2003). Women's vulnerability to HIV has a direct impact on their children and families.

Since 1991, the Federal Ministry of Health has carried out a National HIV/syphilis sentinel seroprevalence survey every 2 years. The HIV/ AIDS prevalence rate has risen from a mere $1.8 \%$ in 1991 to $5.8 \%$ in 2001 but stood at $5 \%$ in 2003. The 2005 survey shows that about $4.4 \%$ of the population is HIV positive (Federal Ministry of Health, 2005). However, it is found that state prevalence rates vary from as low as $1.2 \%$ in Osun state to as high as $12 \%$ in Cross River state. Overall, 13 of Nigeria's 36 states have prevalence rates of over $5 \%$ (Federal Ministry of Health, 2005) ${ }^{24}$ These figures support the claim that there are explosive, localized epidemics in some states. At 5.6\%, HIV/AIDS prevalence rates are highest for young people between the ages of 20 and 24 compared with other age groups. Nigeria's sexually transmitted disease/HIV control estimates that over $60 \%$ of new HIV infections are in the 15- to 25-year-old age group (UNAIDS, 2004). Apart from being the active population, this group also represents the future of the country. Among this group, young women appear to have been worst affected. 
The major mode of HIV transmission in Nigeria is through heterosexual intercourse. It accounts for about $80 \%$ of total infection rate. After South Africa, Nigeria has the second largest number of persons infected with HIV (UNAIDS, 2008) in Africa. Although the prevalence rate in Nigeria is much lower than in South Africa or Zambia, Nigeria has the largest population in Africa ${ }^{25}$ with one in six Africans being a Nigerian. Already life expectancy in that country has dropped from about 53 years in 1990 to about 51 years in 2002, mainly due to HIV infection (Federal Ministry of Health, 2003). If the epidemic continues at its current rate, or worsens, there could be knock-on effects in other West African countries. Factors contributing to the rapid spread of HIV/AIDS in Nigeria include sexual networking practices such as polygamy, high rates of untreated sexually transmitted infections, low condom use, poverty, low literacy, poor health status, low status of women, stigma and denial of HIV/AIDS (Federal Ministry of Health, 2005; UNAIDS, 2003).

There exist various programmes at the federal, state, and local government levels to educate the public about the epidemic and combat its spread in the country. For instance, a multisectoral national body known as the National Action Committee on AIDS (now known as National Agency for the Control of AIDS, NACA) was set up by the federal government around 2000 to coordinate the government's response to the epidemic. In addition, the efforts of the government have been complemented by the activities of non-governmental organizations. Currently there are about 210 centres where antiretroviral drugs can be obtained by those who need them. ${ }^{26}$ However, very few people are accessing treatment. Recently, NACA has claimed that the Nigerian government, with the support of donor agencies, is currently providing treatment for about 350,000 out of about 3 million people living with HIV in the country. ${ }^{27}$ This is about $18 \%$ of those who need treatment, which is a far cry from $28 \%$, the average number of people receiving treatment in the region. ${ }^{28}$ With recent renewed efforts by the government to scale up access to treatment, it is expected that there will be great improvements in near future. However, it should be noted that HIV/AIDS is still highly stigmatized in Nigeria. Indeed it is estimated that about $65 \%$ of the population are not aware of their HIV status (Federal Ministry of Health, 2006).

PUBLIC HEALTH ARGUMENTS SUPPORTING MANDATORY PREMARITAL HIV TESTING IN NIGERIA

Proponents of mandatory premarital HIV testing have argued that such a policy is potentially advantageous to the public. Some of the arguments include the fact that mandatory HIV testing before marriage helps the 
couples to know their status before they are wedded, thereby reducing new infections. The point is that if one of the couples is positive, the other is given the opportunity to opt out, thus reducing the chances of being infected. Supporting this argument, the spokesperson for the Anglican Church in Nigeria has noted that mandatory premarital HIV testing will 'help intending couples to make informed decisions because we don't want anyone to be kept in the dark about their partner. ${ }^{29}$ Also the National Coordinator of the Baptist Church HIV programme in Nigeria has stated that 'We ask [couples to do an HIV test] about nine months or one year before the wedding to know the status of the person they want to marry. If one of them is positive, we ask them if they still want to go ahead, and over 99 percent turn back. Whichever way you look at it, it prevents the spread of the virus'. ${ }^{30}$

In addition, it has been argued that mandatory premarital HIV testing will help to reduce stigma and discrimination since virtually everybody intending to get married will go for an HIV test sooner or later. Some commentators have expressed the view that voluntary counselling and testing has failed since many people refuse the test and continue with their lives without recognizing their risk of HIV infection. ${ }^{31}$ Commenting on this challenge, Venter has stated that 'the Voluntary Counselling model emphasizes choice and free will. It allows people to delay a test, often until that choice is preempted by severe illness, pregnancy or insurance sale. This has proved fatal for the majority of people with AIDS and consumed massive state resources'. ${ }^{32}$ Another important argument is that mandatory premarital HIV testing will reduce the number of children that will be orphaned by HIV/AIDSrelated complications (McQuoid-Mason and Coetzee, 2006). It is further argued that children of a marriage will be saved from HIV infection if couples have been made to undergo HIV testing.

Mandatory HIV testing is also said to promote access to treatment, as people get to know their status early and are able to seek treatment, thus prolonging their lives (Uneke et al, 2007). In other words, mandatory premarital HIV testing advances the realization of the right to life of the citizens. Supporting this view, Cock et al (2003) have argued that in the light of the devastating effect of the epidemic on Africa, the time has come for the world to re-emphasize public health principles that promote communal good over individual rights. Another argument refers to the fact that most unmarried men in Africa, including Nigeria, have a 'main' girlfriend, whom they expect to marry, and one or more other girlfriends with respect to whom they have no similar intention but with whom they engage in sexual intercourse (Meeker and Calves, 1997). It is believed that mandatory premarital HIV testing will discourage this 'promiscuous' attitude among young unmarried people generally (Uneke et al, 2007). It has further been argued that, for an HIV/AIDS prevention strategy to succeed in worst 
affected regions, less emphasis should be placed on consent and providing information for individuals before testing (Cock et al, 2003). This utilitarian reasoning holds that public policy must satisfy the interests of the majority and not the few. That is, communal good must override individual interests.

MANDATORY PREMARITAL HIV TESTING AS A VIOLATION OF HUMAN RIGHTS

Reasonable though the above arguments may seem, it would appear that they lack empirical or statistical data to back them up. Many are based on mere assumptions and ignore the human rights implications of mandatory HIV testing. The argument that mandatory HIV testing will reduce stigma is somewhat exaggerated and does not seem to correlate with available evidence. There is already widespread stigma and discrimination associated with HIV. Mandatory HIV testing may not necessarily translate to behavioural change in people. There have been incidents where people who tested positive to HIV have been subjected to discriminatory practices in the church (Iwuagwu et al, 2003). For instance, there was a case of an HIV-positive woman who was removed as a Sunday school teacher in a church because parents fear she may infect their children (Ukpong, 2003). The challenge for now is to devise a means of combating this stigma through education and putting a human face to the epidemic. A report on the experiences of people living with HIV in Nigeria has shown that they face discrimination virtually in every facet of human endeavour (Center for the Right to Health, 2001). For example, such people are denied employment, housing, health-care and insurance benefits (Center for the Right to Health, 2001). Therefore, forcing people to go for HIV testing without first dealing with the stigma and discrimination will only fuel HIVrelated stigma rather than reduce it.

It has been stated that public health and human rights are interrelated and complement each other. As observed above, public health policy, such as mandatory premarital HIV testing, may have serious implications for human rights, and violations of human rights may result in public health problems. Although it is admitted that a public health policy may limit the enjoyment of human rights, this is always subject to the close scrutiny of human rights law. Thus, limitation to human rights will only be allowed in accordance with the Siracusa principles ${ }^{33}$ as follows:

1. The restriction is provided for and carried out in accordance with the law.

2. The restriction is in the interests of legitimate objective of public interest. 
3. The restrictions are strictly necessary in a democratic society to achieve the objectives.

4. There are no less intrusive and restrictive means to reach the same goals.

5. The restrictions are not imposed arbitrarily - in an unreasonable or discriminatory manner.

Also, it has been provided that rights may be restricted to 'secure due recognition and respect for the rights and freedoms of others; meet the just requirements of morality, public order, and the general welfare; and in times of emergency, when there are threats to the vital interests of the nation. ${ }^{34}$ But, in restricting human rights, it is important to note that certain rights are non-derogable. These include rights to life, dignity, freedom from torture, and freedom from discrimination. Following from the above, therefore, a public health policy that may interfere with the enjoyment of rights will only be justified if it satisfies the principles laid down under international human rights law.

Gruskin and Tarantola (2001) have suggested a framework for analysing the impact of public health policies on human rights. This framework is very important for policy makers as it will help them to determine the effectiveness or otherwise of a proposed public health policy. These include the following questions:

- What is the specific intended purpose of the policy or programme?

- What are the ways and the extent to which the policy or programme may impact positively or negatively on health?

- Using the relevant international human rights documents, what and whose rights are impacted positively or negatively by the policy or programme?

- Does the policy or programme necessitate the restriction of human rights?

- If so, have the criteria/precondition to restrict rights been met?

- Are the health and other related structures and services capable of effectively implementing the policy or programme?

- What system of monitoring, evaluation accountability, and redress exist to ensure that the policy or programme is progressing towards the intended effect and that adverse effects can be acted upon?

Applying this framework to mandatory premarital HIV testing in Nigeria reveals serious implications for the enjoyment of recognized human rights of individuals and its implementation may lead to some serious problems. For instance, how will the already over-burdened health-care institutions manage the logistics of implementing this policy? Are there no other ways of achieving this objective? Are there assurances that individuals' human rights will not be compromised by this policy? In particular, the rights to marry and found a family and to 
non-discrimination will be affected. While one may argue that this policy can advance the health of individuals, the price of this could be isolation and rejection for those who tested positive to HIV. Surely a less intrusive means of ascertaining peoples' HIV status could be adopted. For instance, emphasis could be placed on voluntary counselling and testing, which is more respectful of individuals' rights. The impact of this policy on these rights is now discussed below.

\section{RIGHT TO MARRY}

The right to marry and found a family is a fundamental right adequately guaranteed under Article 23 of the ICCPR. It recognizes the right of adults of marriageable age to enter into a marriage and found a family, without any limitation as to race, nationality, or religion. Article 10 of the ICESCR enjoins states to provide the widest possible protection and assistance to the family, which is the natural and fundamental unit of society. It states further that marriage must be entered into with the free consent of the parties. A similar provision exists in Article 16 of Convention on Elimination of All Forms of Discrimination against Women (CEDAW).$^{35}$ Nigeria has ratified all these treaties. Marriage is a constitutional right, which must be entered into voluntarily without coercion. The right to enter into a marriage freely also implies that an individual should not be prevented from exercising this right. The policy of mandatory HIV testing before marriage will only encourage couples to be denied their fundamental rights to marry and found a family as they are likely to be refused to be wedded in accordance with their wishes, should one of the partners test positive. Although in some cases couples are given the option to either continue or discontinue with the wedding, because of the negative impact of stigma and discrimination, most people are forced to opt out of the wedding. Moreover, experience has shown that church leaders are unable to keep test results confidential but often reveal it to members of the congregation, thereby compounding the problem of stigma and discrimination associated with HIV. ${ }^{36}$

Nigeria has incorporated the African Charter into its domestic law. Article 18 of the African Charter provides that the family shall be the basis of a society. Furthermore, Article 6 of the Protocol to the African Charter on the Rights of Women enjoins states parties to the treaty to ensure that adequate steps are taken to protect women's right to marry. This right relates to the decision of individuals or couples to live together or have a child (Erikson, 2000). In Hamer $v$ United Kingdom, ${ }^{37}$ the European Commission on Human Rights has noted that, while marriage may be regulated by national law, the right to marry guaranteed under Article 12 of the European Convention is such that the regulation 
should not injure the substance of the right. It therefore held admissible a complaint by a prisoner against the refusal to allow him to marry while serving a fixed-term prison sentence.

It should be noted that Nigeria adopts a tri-partite system of law (civil, customary, and Sharia law ${ }^{38}$ and each legal system recognizes different methods of entering into a marriage ${ }^{39}$ Although the right to marry is not a non-derogable right under international law, any limitation on this right as stated earlier must be justified and be in accordance with principles of law. This raises certain questions. Does a state have any right to interfere with the private affairs of its citizens by preventing HIVpositive couples from getting married in the interests of the society? If so, at what point and to what extent can such interference be permitted? These are not easy questions to answer and remain debatable (Felissa and Durham, 2009; Pierce and Van De Veer, 1988). Section 37 of the Nigerian Constitution states: 'The privacy of citizens, their homes, correspondence, telephone conversations and telegraphic communications is hereby guaranteed and protected'. On one occasion, the Human Rights Committee has held that legislation purporting to prohibit a same-sex relationship between consenting adults violates the right to private life. The Committee specifically rejected the contention that such laws can be justified on the public health grounds of curbing the spread of HIV/ AIDS. According to the Committee, criminalization of homosexual practices cannot be considered a reasonable means or proportionate measure to achieve the aim of preventing the spread of HIV/AIDS. ${ }^{40}$ Implicit in this decision is that a state has little, if any, power to interfere in private sexual choices of an individual (Cook et al, 2003). One may rely on this reasoning to argue that undue interference by a state in individuals' rights to enter into a lawful marriage may not be permitted, especially when such rights have been exercised with free will.

Any policy, which requires intending couples to be tested for HIV is likely to undermine the right to found a family. Moreover, mandatory HIV testing for intending couples is an unwarranted intrusion to privacy and also infringes the right to dignity a non-derogable right. ${ }^{41}$ According to the International Guidelines on HIV/AIDS and Human Rights, "it is clear that the right of people living with HIV is infringed by mandatory premarital testing and/or the requirement of 'AIDS-free certificates' as a precondition for the granting of marriage licences under State laws' ${ }^{4}{ }^{2}$ Corroborating this statement, the UN has noted that: ${ }^{43}$

Mandatory premarital HIV testing, coupled with the denial of a marriage licence to those infected with HIV and prohibiting the marriage of individuals known or suspected to be HIV-infected, interferes with the right to marry and found a family.

Gruskin et al have similarly argued that creating obstacles to marriage for HIV-positive people amounts to gross violations of their fundamental 
rights recognized under international law. ${ }^{44}$ Although there is no national policy in Nigeria on compulsory premarital HIV testing, the fact that faith-based organizations are adopting this policy imposes obligations on the government to intervene and stop this act. Under international law, a state has the obligation to respect, protect, and fulfil human rights. The obligation to protect requires a state to ensure that third parties (such as faith-based organizations) do not interfere with the citizens' enjoyment of their rights. Failure to do so would amount to a violation of rights on the part of the government. Cook et al (2003) have argued that a state will be held accountable for failing to prevent violations of women's rights occasioned by religious or customary practices of a third party.

Although Nigerian courts are yet to address the issue of mandatory premarital HIV testing, in $M r . X v$ Hospital $Z,{ }^{45}$ the Indian Supreme Court curiously stated that the right of people who know they have HIV to marry was a 'suspended right' in that country. According to the Court, the law has imposed a duty on a person living with HIV 'not to marry as the marriage would have the effect of spreading his own disease, which is obviously dangerous to life, to the woman he marries'. It was further noted by the Court, albeit judgmentally, that 'AIDS is a product of undisciplined sexual impulse. This impulse, being the notorious human failing if not disciplined, can afflict and overtake anyone how high so ever or for that matter, how low he may be in the social strata'. However, the court's comment was not relevant to the facts before it, which concerned whether medical confidentiality was breached by informing third parties of a patient's known HIV status and whether a person with HIV infection had a duty to inform his or her intended marriage partner of that fact. More recently, the Indian Supreme Court has held that the decision in Mr. Xv Hospital $Z$ should be confined to the facts before the court and that people living with HIV are entitled to exercise their right to marry. ${ }^{46}$ It is hoped that if Nigerian courts are confronted with similar issue the latter position of the Indian Supreme Court will be adopted.

\section{EFFECTS OF MANDATORY PREMARITAL HIV TESTING ON PUBLIC HEALTH}

One of the justifications for advocating mandatory premarital HIV testing is that it will reduce infection rates. Supporting this, Pastor Adeyemi of Day Star Church in Lagos said that, 'We have insisted on couples taking an HIV test before they get married; the results are very, very confidential. And we are doing it to protect them. You see, these things will backfire on the church if people get married and it is after the marriage that one person discovers that the other one is HIV 
positive' ${ }^{47}$ This would seem to be a good idea, which has the potential of reducing HIV infection among married couples. However, this assumption overlooks the fact that at the time of testing couples may be in their window periods, thus either who may already be infected, may yet test negative. In addition, this point makes a very dangerous assumption that couples will always be faithful in marriage. For instance, recent studies in Cambodia found 13\% of urban and 10\% of rural men reported having sex with both a sex worker and their wives or steady girlfriends (UNAIDS, 2004). It has been noted that marriage and other long-term monogamous relationships do not protect women from HIV. ${ }^{48}$ This clearly shows that mandatory premartial HIV testing may not necessarily protect couples from HIV infection (Malhotra et al, 2008).

In many African countries, including Nigeria, it has been shown that unmarried women who tend to have male partners much older than themselves are more likely than young men to be HIV infected. This is traced to poverty in many African communities. There have been documented experiences of young girls in school or out of school being infected by elderly men who are already married (Orubuloye, 1995). The 'sugar daddy' syndrome is well known in many African societies including Nigeria. Young girls in Nigeria, especially undergraduates, have been known to exchange sex for material gains with elderly men, many of whom are married (Bamgbose, 2002). Increase in intergenerational sexual practices has further exacerbated this situation. The result is that more and more young girls are being infected with HIV by married men, which clearly shows that a number of sociocultural factors contribute to the spread of HIV in African countries. These factors are complex and may not necessarily be addressed by a policy of mandatory premarital HIV testing.

It should be noted that the call for mandatory HIV testing for specific groups of people or the population as a whole is not peculiar to Nigeria. Similar calls have recently been made in India, America, and Malaysia. In India, the state of Andhra Pradesh is justifying its proposed law for mandatory premarital HIV testing on the grounds that it will protect women from being infected in marriage and will benefit partners and the generation unborn. ${ }^{49}$ Also, in Malaysia, the call for national legislation to make HIV testing compulsory for intending couples is based on the view that this will protect society from further infection. Already about five predominantly Muslim states have initiated the policy of mandatory premarital HIV testing. ${ }^{50}$

In the USA, about 30 states contemplated adopting the policy of mandatory premarital HIV testing but only two states (Illinois and Louisiana) eventually implemented it (Grostin, 1989). In both states, the policy was discontinued after a short period of time (interestingly, attempts are being made in these states to reintroduce similar legislation). This was because the policy was expensive and many couples 
evaded it by marrying in other states. Moreover, there was no evidence to show that it brought down a reduction in HIV infection rates (Closen et al, 1994). Recent development in South Africa shows that there has been a call for compulsory HIV testing among the entire population. For instance, Venter has recently called for compulsory HIV testing for the entire population. ${ }^{51} \mathrm{He}$ is of the view that this will not only prevent further spread of the epidemic but will also save millions of lives.

\section{RIGHT TO NON-DISCRIMINATION}

Another area of concern about this proposed policy is that it raises a critical issue of discrimination. The right to non-discrimination is guaranteed in numerous human rights instruments. The question may be asked: why target intending couples and not other people who could be at risk? This policy is under-inclusive as it mainly focuses on intending couples, while other people in society who could be at risk are not subjected to similar treatment. The Canadian Supreme Court describes discrimination as: ${ }^{52}$

[a] distinction, whether intentional or not but based on grounds relating to personal characteristics of the individual or group, which has the effect of imposing burdens, obligations, or disadvantages on such individual or group not imposed upon others, or which withholds or limits access to opportunities, benefits, and advantages available to other members of society. Distinctions based on personal characteristics attributed to an individual solely on the basis of association with a group will rarely escape the charge of discrimination, while those based on an individual's merits and capacities will rarely be so classed

Mandatory HIV testing before marriage places an undue burden on intending couples, which other members of society do not share. Although not all discrimination amounts to violation of rights, an adverse discrimination, which occurs when a person is being treated unfairly, is unjustifiable at law (Gruskin and Tarantola, 2001). Discrimination may also violate the dignity of the person. Section 42 of the Nigerian Constitution 1999 forbids discrimination on various grounds including sex, religion, political belief, ethnicity, and race. A similar provision also exists in Article 2 of the African Charter. The African Commission on Human and Peoples' Rights in the case of Legal Resource Foundation $v$ Zambia $^{53}$ has explained the relevance of Articles 2 and 3 of the African Charter dealing with non-discrimination and equal protection of the law. According to the Commission:

The right to equality is very important. It means that citizens should be expected to be treated fairly and justly within the legal system and be assured of equal treatment before the law and equal enjoyments of all the rights available to all 
other citizens. The right to equality is important for a second reason. Equality or lack of it affects the capacity of one to enjoy many other rights.

Nigerian courts have yet to develop a consistent jurisprudence with regard to Section 42 of the Constitution. In Festus Odaife and ors $v$ Attorney General of the Federation and ors, ${ }^{54}$ a Federal High Court held that the non-discriminatory provision of Section 42 of the Nigerian Constitution does not apply to HIV-positive persons. It has been argued that this decision is too restrictive and falls short of international human rights law standards (Durojaye, 2007). This is in sharp contrast to developments in other Commonwealth jurisdictions. For example, in Hoffmann $v$ South African Airways, ${ }^{55}$ the South African Constitutional Court held that a denial of employment to a person solely based on his HIV status violates the equality clause in Section 9 of the Constitution, although the section does not specifically forbid discrimination based on HIV status. The Court gave purposive interpretation to the provision. A similar approach has been adopted in Botswana in the case of Makuto $v$ State ${ }^{56}$ That case concerned the constitutionality of a provision which mandated a higher imprisonment term on someone convicted of rape if they were HIV infected. There the Court gave a generous interpretation to Section 15 of the Botswana Constitution and held that the provision was discriminatory even though the section does not specifically proscribe discrimination based on HIV status. This reasoning of the Court coincides with the recent General Comment of the Committee on Economic, Cultural and Social Rights. ${ }^{57}$

In a society where stigma and discrimination associated with HIV/ AIDS are rife and the health-care system is acutely underfunded and unable to respond positively to the HIV pandemic, subjecting intending couples to mandatory HIV testing will likely aggravate the problem of discrimination related to HIV. Moreover, women would be more affected than men by this policy as they are already disadvantaged and suffer from discriminatory practices. A report has shown that in some parts of the country, HIV-positive women have experienced segregation and violence. ${ }^{58}$ Mandatory premarital HIV testing is likely to expose women to further abuse of their human rights. Sadly enough, most of the incidences of discrimination against HIV-positive persons in Nigeria occur in the health-care setting (Reis et al, 2005); yet, health-care institutions ought to be places where HIV positive persons should find comfort and support. During the UN Declaration of Commitments in $2001,{ }^{59}$ it was agreed that countries should enact legislation specifically addressing HIV-related discrimination by 2003, Nigeria is yet to keep this promise.

Apart from the human rights implications, the policy may also raise some administrative problems. In a country like Nigeria with a population of about 140 million people, proper monitoring of the 
practice of the policy may prove difficult. It could encourage the use of fake certificates; people are likely to look for ways to beat the system, thereby defeating the whole essence of compulsory testing before marriage. Advocates of this policy also do not seem to take into account customary marriages, which are often conducted between families without any formalities. In such situations how does one monitor compliance?

\section{CONCLUSION}

From the above discussion it would appear that mandatory premarital HIV testing may not achieve the intended results. An alternative would be to encourage voluntary counselling and testing before marriage in a voluntary basis. This would be more productive, less costly, and avoid the human rights implications of mandatory testing. In addition, there should be greater political commitments to deal with HIV/AIDSrelated stigma and discrimination. Unless Nigerian society can deal decisively with stigma and discrimination, any policy targeted at reducing the spread of the epidemic may not achieve its desired aims. If traditional leaders and political rulers were to publicly declare their intention to undergo an HIV test, this alone would have a great impact in demystifying HIV/AIDS as a disease of the 'outcast', as some people call it. Finally, it is necessary to make treatment more available and affordable for those who need it.

\section{NOTES}

\footnotetext{
${ }^{1}$ See Plus News "Nigeria 'With this HIV test I wed thee" available at http:/ www.plusnews.org /Report.aspx?ReportId=81573 (accessed on 20 October 2009).

${ }^{2}$ See J. Ibekwe, 'Breaking the Silence in Nigeria: An Appeal to the President (2000) Impact on HIV, available at http://www.fhi.org/en/HIVAIDS/pub/Archive/articles/IOH/ioh22/ioh-nigeria.htm (accessed on 12 October 2009).

${ }^{3}$ See for instance, C. Odimegwu, 'Prevalence and Predictors of HIV-related Stigma and Knowledge in Nigeria: Implications for HIV/AIDS Prevention Initiatives' (A Research Report) (2002) available at http://www.hsph.harvard.edu/research/takemi/files/RP210.pdf (accessed on 9 November 2009); see also, Open Society Institute Public Health FACT Sheet: women and HIV testing policies, practices and the impact on Health and Human Rights available at soros.or g/initiatives/health/focus/. . / womenhiv_20080730.pdf (accessed on 10 November 2009).

${ }^{4}$ The Constitution of the World Health Organization (WHO). 14 UNTS 185 was adopted by the International Health Conference, New York, 19-22 June 1945; opened for signature on 22 July 1946 by the representatives of 61 States (Official Records of the World Health Organization, no. 2, p. 100); and entered into force on 7 April 1948.

${ }^{5}$ Universal Declaration of Human Rights, G.A. Res. 217 A (III), U.N. Doc. A/810 (10 December 1948).

${ }^{6}$ ICESCR, adopted 16 December 1966; GA Res 2200 (XXI), UN Doc A/6316 (1966) 993 UNTS 3 (entered into force 3 January 1976).

${ }^{7}$ Ibid., Art 12 (2).

${ }^{8}$ See The Right to the Highest Attainable Standard of Health; UN Committee on ESCR General Comment No 14, UN Doc E/C/12/2000/4.
} 
${ }^{9}$ Ibid., para 8.

${ }^{10}$ Ibid.

${ }^{11}$ Ibid.

${ }^{12}$ See Pachim Banga Khet Majoor Samity v State of West Bangal [1996] AIR SC 2426.

${ }^{13}$ The Right to Life UN GAOR Human Rights Committee 37th session Supp No. 40.

${ }^{14}$ See, for instance, Chapter 2 of the Constitution of Nigeria 1999, which contains a number of socio-economic rights that are said to be non-justiciable by virtue of section 6 (6) of the Constitution.

${ }^{15}$ African Charter on Human and Peoples' Rights O.A.U. Doc.CAB/LEG/67/3/Rev.5, adopted by the Organization of African Unity, 27 June 1981, entered into force 21 October 1986.

${ }^{16}$ Protocol to the African Charter on the Rights of Women was approved by the Assembly of African Union in 2003, it came into force on 25 November 2005.

${ }^{17}$ Communication 241/2001 decided at the 33rd Ordinary Session of the African Commission held from 15 to 29 in Niamey, Niger, May 2003, para 80.

${ }^{18}$ This has been made possible by virtue of the African Charter on Human and Peoples Rights (Enforcement and Ratification) Act Cap 10 Laws of the Federation 1990.

${ }^{19} 197$ U.S. 11 (1905).

${ }^{20}$ S. Gruskin and D. Tarantola, 'Human Rights and HIV/AIDS', available at http:/ /www.hivinsite .ucsf.edu/InSite (accessed on 21 August 2009).

${ }^{21}$ Article 4 of the ICESCR.

${ }^{22}$ See article $12(2)$ (c) of the ICESCR.

${ }^{23}$ NACA, Situation Analysis Report on STIS/HIV/AIDS in Nigeria, available at http://www .nigeria-aids.org (accessed on 5 August 2009).

${ }^{24}$ Ibid.

${ }^{25}$ Nigeria's population is estimated by the National Population Commission report of 2003 at $128,771.988$ million; and an annual growth rate of $2.7 \%$.

${ }^{26}$ Journalists Against AIDS in Nigeria, 'Location of national antiretroviral therapy sites', available at http://www.nigeria-aids.org/pdf/All_ART_Sites.pdf (accessed on 2 May 2009).

${ }^{27}$ Ben Ukwuoma, 'Nigeria records 370, 000 new HIV infections yearly, says NACA', The Guardian Newspaper, 14 September 2009.

${ }^{28}$ WHO, Towards Universal Access Scaling Up Priority HIV/AIDS in the Health Sector, available at http ://www.searo.who.int/en/Section10/Section18/Section2008_13202.htm (April 2007) (last accessed on 14 August 2009).

${ }^{29}$ See Kendall Harmon, 'Nigeria: Anglican Church Reaffirms HIV Test before Marriage', available at http://www.kendallharmon.net/t19/index.php/t19/article/5218/ (accessed on 10 September 2009).

${ }^{30}$ Plus News, "Nigeria "With this HIV test I wed thee"' note 1 above.

${ }^{31}$ F. Venter, 'Make HIV Testing Compulsory for South Africans' 3 June 2007, Sunday Times of South Africa.

${ }^{32}$ Ibid.

${ }^{33}$ United Nations Economic and Social Council, (1985), The Siracusa Principles on the limitation and derogation provisions in the International Covenant on Civil and Political Rights, UN Doc $\mathrm{ECN} / 4 / 1985 / 4$ Annex.

${ }^{34}$ See Article 4 of the International Convenient on Civil and Political Rights (ICCPR) G.A. Res. 2200, U.N GAOR, Supp. No. 16 at 52, U.N Doc. A/6316 (1966), 999 U.N.T.S. 171, 174 (entered into force on March 23 1976).

${ }^{35}$ Convention on the Elimination of All Forms of Discrimination against Women GA Res 54/180 UN GAOR 34th Session Supp No 46 UN Doc A/34/46 1980.

${ }^{36}$ Public Agenda, 'Participants Kick against HIV/AIDS Mandatory Test before Marriage' available at http://allafrica.com/stories/200910271138.html (accessed on 11 November 2009).

${ }^{37}$ (1979) 24 DR 5, 14 Eur Comm HR 35.

${ }^{38}$ More information on the laws of the Federal Republic of Nigeria is available at www.nigerialaw.org or www.nigeria-law.org/CourttOfAppeal.htm (accessed on 10 April 2008); see also BAOBAB, The Nigeria CEDAW NGO Coalition Shadow Report submitted to the 41st Session CEDAW 30 June-18 July 2008. The Committee on CEDAW was to review the Government of Nigeria's 6th Periodic Country Report (2004-2008) on the implementation of CEDAW in Nigeria, available at http//www2.ohchr.org/english/bodies/cedaw/docs/ngos (accessed on 20 July 2008); BAOBAB, Women's Access to Justice and Personal Security: A synthesis Report BAOBAB Women Human Rights (2003), available at http:/ / www2.ohchr.org/english/bodies/cedaw/docs/ngos/BAOBADNigeria 41.pdf (accessed on 13 July 2009). 
${ }^{39}$ Marriage Act Cap. 218, 1990; see also Sharia Court of Appeal Act 1967, giving Sharia courts the power to decide on matters of personal status, marriage, and succession; see also Marriages (Validation) Act Cap. 219, 1990, this applies to all marriages within the country.

${ }^{40}$ Toonen v Australia UN GAOR, Human Rights Committee 15th Session, Case 488/1992 UN DocCCPR/C/D/488/1992 April 1994.

${ }^{41}$ The South African Constitutional Court in Hoffman case held that a denial of employment to a person who is HIV positive violates the right to dignity and non-discrimination guaranteed under South African Constitution.

${ }^{42}$ Adopted at the Third International Consultation on HIV/AIDS and Human Rights (Geneva 25 July 2002), organized by the Human Rights Office of the United Nations High Commissioner for Human Rights and Joint United Nations Programme on HIV/AIDS.

${ }^{43}$ United Nations Commission for Human Rights (UNCHR). (1994) Report of the Secretary General on International and Domestic Measures Taken to Protect Human Rights and Prevent Discrimination in the Context of HIV/AIDS E/CN4/45 Geneva.

${ }^{44}$ S. Gruskin et al, 'Reproductive Health and HIV: Do International Human Rights Law Matter? Available at www.hsph.harvard.edu/pihhr/files/ReproHealthJSDLP.pdf (accessed on 3 May 2009).

${ }^{45}$ Mr. X v. Hospital Z, AIR 1999 SC PG 495.

${ }^{46} \mathrm{Mr} . X v$ Hospital Z 2002 SCCL.COM 701 (SC).

${ }^{47}$ D. Thomas, 'Why We Conduct HIV Test' Sunday Punch Newspaper, 16 September 2007.

${ }^{48}$ Ibid.

${ }^{49}$ See The Economy 'Andra to make Premarital HIV testing Mandatory', 17 April 2007 available at http://economictimes.indiatimes.com/articleshow/msid-1918444,prtpage-1.cms (accessed on 26 October 2009).

${ }^{50}$ See The Star Newspaper Online 'Study Needed Before Making HIV Testing Mandatory' 21 December 2008 available at http://thestar.com.my/news/story.asp?file=/2008/12/21

${ }^{51}$ F. Venter, 'Make HIV Test Compulsory for South Africans', note 31 above.

${ }^{52}$ Andrews v Law Society of British Columbia [1989] 1 SCR 143.

${ }^{53}$ Legal Resource Foundation v Zambia (2001) AHRLP 84 (ACHPR 2001) para 63.

${ }^{54}$ (2004) AHRLR 205 (NgHC).

${ }^{55}$ [2000] 11 BCLR 1235 (CC).

${ }^{56}$ (2000) 5 LRC 183 (Bostwana Court of Appeal).

${ }^{57}$ The Committee in its General Comment 20 on Non-Discrimination in Economic, Social and Cultural Rights E/C.12/GC/20 25 May 2009 has explained that the phrase 'other status' in human rights instruments embraces health status including HIV status.

${ }^{58} \mathrm{O}$. Falobi, 'Beyond the Shadow: Unmasking HIV/AIDS-related Stigma and Discrimination in Nigeria' (2004) available at www.nigeriaaids.org (accessed on 12 May 2009).

${ }^{58}$ UN General Assembly Special Session on HIV/AIDS Resolution A/S-26/L2 June 2001.

\section{REFERENCES}

Albertyn, C. (2000) 'Using rights and the law to reduce women's vulnerability to HIV', Canadian HIV/AIDS Policy and Law Review 5, 72-79.

Bamgbose, O. (2002) Teenage prostitution in Nigeria, International Journal of Offender Therapy and Comparative Criminology 42, 569-85.

Center for the Right to Health. (2001) HIV/AIDS and Human Rights: Experiences of People Living with HIV/AIDS in Nigeria, Lagos: Center for the Right to Health.

Center for Reproductive Rights. (2005) Briefing Paper: The Protocol on the Rights of Women in Africa: An Instrument for Advancing Reproductive and Sexual Rights, New York: Centre for Reproductive Rights.

Closen, M., Gamrath, R. and Hopkins, D. (1994) 'Mandatory premarital HIV testing: political Exploitation of the AIDS Epidemic', Tulane Law Review 69(1), 71-115.

Closen, M. and Wojcik, M. (1990) 'International health law, international travel restrictions and the human rights of persons with AIDS and HIV', Touro Journal of Transitional law 1, 285-306.

Cock, K. M., Marum, E. and Mbori-Ngacha, D. (2003) 'A serostatus-based approach to HIV/AIDS Prevention and Care in Africa', The Lancet 362, 1847-49.

Cook, R. J., Dickens, B. M. and Fathalla, M. F. (2003) Reproductive Health and Human Rights: Integrating Medicine, Ethics and Law, Oxford: Oxford University Press. 
Durojaye, E. (2006) 'Advancing gender equity in access to HIV treatment through the protocol to the African Charter on the rights of women', African Human Rights Law Journal 6, 187-207.

Durojaye, E. (2007) 'Discrimination based on HIV/AIDS status: a comparative analysis of the Nigerian's court decision in Festus Odaife and ors $v$ Attorney General of the Federation and ors with other commonwealth jurisdictions', Law Democracy and Development 11, 133-51.

Durton, D. B. and Levine, S. (1989) 'Overview, methodological critique and reformulation' in J. Bunker, D. Gomby and B. Kehrer (eds), Pathways to Health: The Role of Social Factors, Menlo Park CA: J Kaiser Family Foundation, 29-69.

Erikson, M. K. (2000) Reproductive Freedom: In the Context of International Human Rights and Humanitarian Law, The Hague: Kluwer Law International.

Federal Ministry of Health (2003) National Seroprevalence Sentinel Report, Abuja: Federal Ministry of Health.

Federal Ministry of Health (2005) National Seroprevalence Sentinel Report, Abuja: Federal Ministry of Health.

Federal Ministry of Health (2006) Report on the Study on Access to Healthcare for People Living with HIV and AIDS in Nigeria 2002, Abuja: Federal Ministry of Health.

Felissa, R. and Durham, J. (2009) The Persons with HIV/AIDS Nursing Perspectives, New York: Springer.

Fidler, D. P. (1999) International Law and Infectious Diseases, Oxford: Oxford Press.

Goldfeld, A., Mollica, R., Pesavento, B. and Faraone, S. (1988) 'The physical and psychological squeal of torture: symptomatology and diagnosis', Journal of the American Medical Association 259, 2725-29.

Gostin, L. O. and Berkman, B. E. (2007) 'Pandemic Influenza in Ethics, Law, and the Public's Health', Administrative Law Review 59, 121-175.

Grostin, D. (1989) 'Public health strategies for confronting AIDS legislative and regulatory policy in the United States', Journal of American Medical Association 261, 1621-30.

Gruskin, S. and Tarantola, D. (2000) HIV/AIDS, Health and Human Rights: Handbook for the Design and Management of HIV/AIDS Prevention and Care Programmes in Resource Constrained Setting, Arlington, VA: Family Health International.

Gruskin, S. and Tarantola, D. (2001) 'Health and human rights' in R. Detels and R. Beaglehole (eds), Oxford Textbook on Public Health, Oxford: Oxford Press, 311-335.

Iwuagwu, S., Durojaye, E., Oyebola, B., Oluduro, O. and Ayankogbe, O. (2003) HIV/AIDS and Human Rights in Nigeria: Background paper for Polci Review, Washington DC: Futures Group International/Policy Project.

Kirby, M. D. (2004) 'Never ending paradoxes of HIV/AIDS and human rights', African Human Rights Law Journal 4, 163-80.

Malhotra, R., Malhotra, C. and Sharma, N. (2008) 'Should there be mandatory HIV testing prior to marriage in India?', Indian Journal of Medical Ethics 2, 70-74.

Mann, J. M., Gostin, L., Gruskin, S., Brennan, T., Lazzarini, Z. and Fineberg, H. (1994) 'Health and human rights', Health and Human Rights 1, 6-23.

McQuoid-Mason, D. and Coetzee, L. (2006) HIV/AIDS, the Law and Human Rights Resource Manual, Durban: Centre for Socia-Legal Studies.

Meeker, S. and Calves, A. E. (1997) 'Main girlfriends, girlfriends, marriage and money: the social context of HIV risk behaviour in sub-Saharan Africa', Health Transition Review 7, 361-75.

Orubuloye, I. O. (1995) 'Pattern of sexual behaviour of high risk and the implication for STDs and HIV/AIDS Transmission in Nigeria' in R. G. Parker and J. H. Gagnon (eds), Conceiving Sexuality: Approaches to Sex Research in a Postmodern World, New York: Rutledge, 235-246.

Parmet, W., Goodman, R. and Farber, A. (2005) 'Individual rights versus public's health: 100 years after Jacobson and Massachusetts', New England Journal of Medicine 352, 652-54.

Pierce, C. and Van De Veer, D. (1988) AIDS, Ethics and Public Policy. Belmont, CA: Wadsworth.

Reis, C., Heisler, M., Amowitz, L. L., Mooreland, R. S. and Mafeni, J. O. (2005) 'Discriminatory attitudes and practices by health care workers towards patients with HIV/AIDS in Nigeria', PLoS Medicine e246 (2), 0743-0754.

UNAIDS (2003) Update Report on HIV/AIDS Epidemic, Geneva: UNAIDS.

UNAIDS (2004) Update Report on HIV/AIDS Epidemic, Geneva: UNAIDS.

UNAIDS (2008) Update Report on HIV/AIDS Epidemic, Geneva: UNAIDS.

Uneke, C. J., Alo, M. and Ogbu, O. (2007) 'Mandatory premarital HIV testing in Nigeria: the public health and social implications', AIDS Care 1, 116-121.

Ukpong, M. (2003) An Analysis of the Policies, Pronouncements and Programmes on HIV-related Stigma and Discrimination in Nigeria, Lagos: Journalists Against AIDS. 